\title{
ELITES POLÍTICAS MATO-GROSSENSES E AS DISPUTAS OLIGÁRQUICAS DE 1892, 1899 E 1906
}

\section{Larissa Rodrigues Vacari de Arruda ${ }^{1}$}

Resumo: O presente trabalho objetiva analisar a configuração das disputas entre as elites políticas no Mato Grosso, a fim de explicar sua ligação com as Disputas Oligárquicas de 1892, 1899 e 1906. Será feita uma reconstrução histórica, política e social para explicar a ligação das elites e com os processos políticos a luz da bibliográfica consagrada de autores como Leal (1975) e Queiroz (1976). Tendo como hipótese principal que os arranjos e rearranjos políticos, as contradições que configuram o comportamento dessas elites foram a causas das Disputas Oligárquicas. As elites republicanas eram arraigadas de resquícios históricos que muito dificultaram a implantação de uma ordem democrática na Primeira República, mas os atores encontraram uma forma de institucionalizar suas práticas políticas.

Palavras-chave: Mato Grosso, Disputas Oligárquicas, Primeira República.

Resumen: Este trabajo tiene como objetivo analizar la configuración de las disputas entre las elites políticas en Mato Grosso, con el fin de explicar su relación con los conflictos oligárquicos 1892, 1899 y 1906. Habrá una reconstrucción histórica, política y social para explicar las elites de enlace y los procesos políticos de la literatura luz de autores consagrados como Leal (1975) y Queiroz (1976). La hipótesis de que los principales acuerdos políticos y reordenamientos, las contradicciones que determinan el comportamiento de estas elites fueron las causas de las disputas oligárquicas. Las elites republicanas estaban enraizadas en restos históricos que muy difícil de poner en práctica un orden democrático en la Primera República, pero los agentes encontraron una manera de institucionalizar sus prácticas políticas.

Palabras-Clave: Mato Grosso, Revoluciones, Antigua República.

Abstract: This paper aims to analyze the configuration of the disputes between the political elites in Mato Grosso, in order to explain his connection with the Disputes oligarchic 1892, 1899 and 1906. There will be a historical reconstruction, political and social to explain the link elites and the political processes of the light literature of authors as consecrated Leal (1975) and Queiroz (1976). The hypothesis that the main political arrangements and rearrangements, the contradictions that shape the behavior of these elites were the causes of disputes oligarchic. The republican elites were rooted in historical remnants that very difficult to implement a democratic order in the First Republic, but the actors found a way to institutionalize their political practices.

Keywords: Mato Grosso, Disputes Oligarchic, First Republic.

${ }^{1}$ Mestranda em Ciência Política pela UFSCar (Universidade Federal de São Carlos) 


\section{I- Introdução}

O movimento de centralização-descentralização do governo foi um processo frequente em nossa história. O período a ser tratado neste artigo, a Primeira República Brasileira, sucedeu a centralização do II Reinado, que, por sua vez, antecedia a descentralização implementada pelo período Regencial. A República Oligárquica trouxe o advento do federalismo e sua consequente descentralização.

É consenso na literatura que o referido período nada tinha de democrático ou republicano. Seu arranjo se baseava da esfera municipal para estadual no coronelismo, e da esfera estadual para federal na denominada "política dos governadores".

O Coronelismo é o compromisso entre o poder público progressivamente fortalecido, e o poder privado, que necessitava da legitimação do poder público para exercer um poder que outrora era inquestionavelmente apenas seu (LEAL, 1975, p.2057). Dessa união resulta a ambiguidade entre as esferas, cuja nitidez é tão necessária para a ordem democrática.

O governo estadual dava carta branca ao coronel no município para fazer o que quisesse, em troca o coronel apoiava os candidatos estaduais. O mesmo ocorria do âmbito federal para o estadual. Campos Sales implementa a política dos governadores, quando era dada carta branca aos governadores nos seus estados desde que se comprometessem a apoiar candidatos que estivessem de acordo com governo federal. "Era em escala federal, a mesma combinação existente no plano estadual, entre presidentes e coronéis: dá-me teu apoio e terás carta branca” (QUEIROZ, 1976, p.122).

Segundo Queiroz (2006, p.164-168) o coronel é líder de sua parentela e das parentelas aliadas, sua autoridade transborda a nível local e regional, podendo se estender ao nacional. A parentela "era formada por um grande grupo de indivíduos reunidos entre si por laços de parentesco carnal, espiritual (compadrio), ou de aliança (uniões matrimoniais)" (QUEIROZ,2006, p.164).

A parentela oferecia vantagens a todos seus membros, pois todos eram cobertos pelos laços de solidariedade, caso passasse por algum problema. A parentela permitia o empreendedorismo, pois era certo que seus membros seriam amparados. Era um grupo econômico e político, garantindo lealdade dos membros para com os chefes.

O coronel, além de ser o chefe de uma parentela, contava com outro mecanismo para assegurar seu poder, a Comissão de Verificação de Poderes. A Comissão garantia que por mais que um candidato tivesse expressiva votação, mas se oposicionista, não seria diplomado, ou seja, a oposição não assumia mandato. Ainda se houvesse 
competição igual, conforme Leal (1975, p.52), a população votaria no candidato governista, pois tinha maior probabilidade de arraigar melhorias para o município.

Queiroz (1976, p.122) pontua que a configuração republicana que eliminava a democracia, era a única forma para assegurar a estabilidade de um regime construído sobre bases tão precárias. Assim, as interpretações sobre o período são quase sempre negativas, quando as instituições democráticas estiveram subvertidas a lógica patrimonial, pessoalista, mandonista. Longe de discordar que falta "espírito" democrático, republicano, pontuo que o resultado era esperado, pois as instituições democráticas foram postas em uma ambiente não propicio a elas (FERNANDES,2008, p.93-122).

A compreensão dos fatos históricos do antigo Mato Grosso $\mathrm{Uno}^{2}$, implica em lançar luz sobre a história atual do Mato Grosso e Mato Grosso do Sul. Interessante notar que as famílias que se dividiam no poder durante a Primeira República, permaneceram no comando político estadual por longo período, misturando-se a novas lideranças.

Ainda hoje existe a preponderância dos grupos de familiares, ou segundo Neves (2001), da "familiocracia”, tais como os Sarney no Maranhão, os Magalhães na Bahia, os Covas em São Paulo, e os Trad em Mato Grosso do Sul. Neste estado um exemplo é o deputado Londres Machado, deputado há 40 anos e reeleito deputado estadual em 2010. O caso da família Trad, porém, é mais significativo. Os Trad, conhecido como Nelsinho, Marquinhos e Fábio, ocuparam a prefeitura da capital, elegeram-se deputado federal e estadual em 2010. Assim, existe uma série de fatos, tanto na República Velha como por todo o século XX, que necessitam de uma pormenorizada apreciação.

O estudo do período proposto (1892-1906) também significa elucidar a importância histórica e política dos dois estados (MT e MS) para o país, que parecem esquecidos. Permanece adormecida a importância da questão platina para consolidação do estado nacional no Império (FERREIRA, 2009, p.23), a Rusga enquanto movimento nativista de 1834, a recepção do Sul do Mato Grosso ao Tenentismo e a Coluna Prestes, enquanto o norte perseguiu a Coluna. Da Coluna resultou uma tentativa de separatismo, que foi o Estado da Brasilândia em 1924. Como também é ignorada a participação do sul do Mato Grosso Uno na Revolução de 1932 ao lado de São Paulo. Contrariando o posicionamento da capital Cuiabá, que apoiou Getúlio e lutou contra a separação do estado, o sul apoia e participa da Revolução de 32 com objetivo de concretizar a divisão do estado, ambicionada desde fins do século XIX.

\footnotetext{
2 Refere-se ao período que o estado do Mato Grosso compreendia os estados de Rondônia, Mato Grosso do Sul, além do território de Mato Grosso.
} 
Dessa forma, será analisado como as disputas entre as elites do estado do Mato Grosso interferiram e conduziram a política da época. Objetiva-se explicar as disputas e contradições entre as mesmas e sua relação na produção das chamadas Disputas Oligárquicas de 1892, 1899 e 1906. Tendo como hipótese principal que a disputas entre as elites produziu os conflitos, assim como a morte do governador Antônio Paes de Barros.

Através de uma reconstrução da história, da política e da sociedade da República será analisado, sob a luz das obras de Leal e Queiroz, a relação entre as elites e a política. A próxima seção apresentará as elites mato-grossenses: as principais oligarquias no período analisado, seu perfil, sua influência e relação com a política, além da situação de subordinação do sul do estado pelo norte.

Em seguida serão reconstruídos os conflitos de 1892, 1899 e 1906 e ressaltado o "padrão de conflito", as recomposições e arranjos, ou seja, as contradições das elites. Na sequência argumentarei sobre a racionalidade política dos atores, que se focado na perspectiva da democracia são contraditórias, porém da forma como foi implantada a República no país, onde as noções de democracia, república, liberalismo eram meras abstrações distantes, perceberemos que esses atores agiram segundo sua racionalidade.

\section{II- Elites Mato-Grossenses}

Corrêa (2006, p.59-60) ressalta que desde o final da Monarquia a elite política era composta por coronéis proprietários e também por coronéis urbanos. Entre os últimos existiam grandes comerciantes, profissionais liberais, pequenos comerciantes e funcionários públicos.

Dessa estrutura política mato-grossense surgiram grupos oligárquicos, como por exemplo, os Murtinhos, os Corrêa da Costa, os Ponce, os Barros, os Celestinos, que se sustentaram no poder na medida em que mantiveram o respeito pela independência dos coronéis locais em seus respectivos domínios (CORRÊA, 2006, p.61). As principais oligarquias que durante a República Velha estiveram nas disputas pelo poder foram: os Murtinho, os Ponce, os Corrêa da Costa, os Paes de Barros.

É interessante observar outra questão acerca da luta pelo poder no período: o sul do Mato Grosso, atual Mato Grosso do Sul, e o norte do Mato Grosso, foram duas regiões distintas desde a Colonização (NEVES, 2001, p.45-48). Devido à preponderância econômica, o sul do estado reivindicava alguma participação política. Os dirigentes do norte sempre subjugaram os do sul, todos os benefícios vinham exclusivamente para o norte, sendo que a maior receita de impostos vinha do sul (QUEIROZ, 2010, p.125-146). Diante desse quadro as reivindicações pela divisão do estado vêm desde fins do século XIX, aproximadamente 1892 (CORRÊA,2006, p.63). 
Assim, a configuração política do norte de imensa disputa, como será esmiuçado adiante, os coronéis do sul em estratégia para obter o poder incentivaram o separatismo como a única forma de participar do jogo político. "O processo de conquista de poder se manifestou na ideologia separatista" (NEVES, 2001, p.50).

Enquanto isso, no norte do estado uma oligarquia se consolidava no advento da República. Os Murtinho já haviam estado na presidência da província durante o Império. José Antônio Murtinho (1814-1888) foi um médico baiano, tenente do exército no Mato Grosso, e presidente da província em 1868.

O mais ilustre dos Murtinho foi seu filho, Joaquim Murtinho (1848-1911), médico renomado (tratou de Deodoro da Fonseca, Benjamin Constant, Prudente de Moraes, Campos Salles, senadores, deputados, presidentes de província) engenheiro, catedrático em Medicina, senador, ministro da Fazenda e empresário. Cuiabano deixara a terra natal aos 13 anos e nunca mais voltou, entretanto não deixou de influenciar seu estado.

Manuel José Murtinho, irmão de Joaquim foi presidente do estado do Mato Grosso e ministro do Supremo Tribunal Federal. José Antônio Murtinho (1847-1930) também era médico e foi senador. Francisco Murtinho presidiu do Banco Rio e Mato Grosso, que era uma das propriedades da família, assim como a Companhia Erva Mate Laranjeira e a Companhia Ferro Carril Carioca (FARIA, 1993, p.216-232).

Já os Ponce eram uma oligarquia em ascensão e que teria preponderância não só na Primeira República. O coronel da Guarda Nacional Generoso Ponce (1852-1911), título que recebera diretamente do presidente Floriano Peixoto (MENEZES,2007, p.38) se alistou na Guerra do Paraguai aos treze anos e saiu como primeiro-sargento cadete. Em sua biografia disponível no site do Senado Federal consta como sua profissão agricultor, comerciante, jornalista e proprietário rural. Embora seu filho Generoso Ponce Filho (1967, p.135) cite que seu pai não gostava de ser fazendeiro devido a um trauma relacionado a um incêndio em uma propriedade do mesmo, em sua juventude. "Deve tê-lo impressionado muito esse desastre inicial, a ponto de nunca ter sido fazendeiro, quando o comércio lhe deu prosperidade e recursos que o poderiam levar a ser grande latifundiário" (PONCE FILHO, 1967, p.135).

Generoso Ponce foi ainda deputado provincial, deputado estadual, senador, deputado federal e presidente da província do Mato Grosso. No período posterior a 1911, quando falecem no mesmo mês de novembro Joaquim Murtinho e Ponce, os últimos tomam parte da liderança política estadual em detrimento dos primeiros. Adelina, segunda filha de Ponce, casa-se com o coronel João Pedro de Arruda. Dessa união saem duas lideranças políticas do estado, o neto de Ponce João Ponce de Arruda (1904-1979). E a outra liderança importante da família Ponce, dá-se na aliança entre os 
Ponce e os Müller, a neta de Ponce Maria de Arruda Müller (1898-2003) casa-se com Júlio Müller, irmão de Filinto Müller.

Os Corrêa da Costa estiveram oito vezes no poder do estado desde o Império. Antônio Corrêa (pai e filho) foram presidentes durante Império e República, como também Mário Corrêa na Primeira República, Fernando Corrêa da Costa foi governador em 1960 pela UDN, pleito que disputou com João Ponce de Arruda, candidato pelo PSD. O coronel Pedro Celestino Corrêa da Costa também fora uma importante liderança.

No período imediato após a morte de Ponce e Joaquim, ficaram como liderança política o senador Azeredo e Pedro Celestino. Os dois se desentendem por causa da Companhia Erva Mate Laranjeira, resultando na cisão. Azeredo passou, então, a liderar o Partido Republicano Conservador, enquanto Pedro Celestino fundou o Partido Republicano Mato-Grossense. Mário Corrêa quando era presidente do estado, em 1926, rompeu com seu tio Pedro Celestino e fundou o Partido Democrata Mato-Grossense.

A oligarquia dos coronéis Paes de Barros tem como membro mais expressivo o presidente de estado Antônio Paes de Barros. Também formada por seus irmãos os coronéis João, Henrique e José Paes de Barros. Antônio Paes de Barros, o Totó Paes era um rico usineiro de açúcar. Sua usina era muito bem equipada, tinha máquinas da Alemanha, onde existiu luz elétrica primeiro que em Cuiabá. Era chefe local aliado do coronel Generoso Ponce.

Um fator importante dessa oligarquia foi a rivalidade e a oposição entre os irmãos Totó e João, que tem como ápice o Massacre da Bacia do Garcez. Depois da Disputa Oligárquica de 1899, quando Totó Paes se consolidou como figura eminente na política estadual os dois irmãos cindem. Carone (1969) publica o relato de João Paes de Barros sobre o Massacre da Bacia do Garcez. João, era vice-presidente, assumiu provisoriamente o governo do estado, tomando atitudes liberais em favor da oposição.

Em 1901 João reuniu em sua fazenda pessoas que se opunham ao governo, do qual seu irmão era aliado. Totó enviou uma expedição a usina da Conceição, que pertencia a João. Henrique e José Paes de Barros foram à usina intimidar o irmão a mando de Totó. Havia 140 asilados políticos na casa de João, que não é preso, porém ficou em prisão domiciliar.

Foi trazida de Cuiabá uma lista pelo chefe de polícia que dever-se-ia separar os presos em três grupos. O primeiro grupo seguiria por terra e era composto por 16 pessoas. O segundo seguiria por água em lanchas, ao todo 100 pessoas. $\mathrm{O}$ terceiro grupo aguardaria na usina, que fora destruída.

O grupo que seguira por terra foi assassinado no dia 04/11/1901; os cadáveres tinham o ventre partido em cruz e foram jogados para as piranhas, os guardas ficaram 
esperando os corpos desaparecerem no rio. "Ao cair da noite parte da escolta que seguira com os presos por terra, regressara à usina, narrando sem reservas os horrorosos detalhes da carnificina da Bacia do Garcez” (CARONE, 1969, p.83). João Paes foi obrigado a renunciar a vice-presidência do estado e se aliou a Ponce, inimigo de Totó. Menezes (2007) cita que em Cuiabá a morte de Totó era justificada pelo massacre da Bacia do Garcez.

Dessa maneira as quatro famílias citadas, de acordo com Neves (2001), vivenciaram uma "dinâmica do conflito" onde a disputa pela hegemonia gerava padrões de conflito, recomposição e arranjos. "Oriento-me pela premissa de que a luta pela hegemonia política, nesse modelo mato-grossense, manifestou-se em etapas sucessivas de recomposições e novos conflitos, cujas formas de encaminhamento foram o confronto ou o arranjo - uma dinâmica do conflito" (NEVES, 2001, p.68).

Ainda segundo Neves, o conflito dos coronéis do norte tratava-se da obtenção do domínio sobre as esferas do poder público, inclusive os partidos republicanos. Os partidos no estado foram coadjuvantes utilizados como mero instrumento da rivalidade entre os grupos, onde a qualquer dissabor entre líderes era formada uma nova sigla, revelando o caráter fortemente personalista. Fora o auge da oligarquização partidária.

As oligarquias aqui apresentadas, com principal destaque para os Murtinho e os Ponce, lutaram contra o inimigo comum, posteriormente guerrearam entre si, unindose novamente. Nesses jogos contraditórios se desenrolam os três conflitos em 1892, 1899 e 1906.

\section{III- A Disputa Oligárquica de 1892 e o "Estado Livre do Mato Grosso"}

Com a chegada da República, Deodoro nomeou Antônio Maria Coelho para presidência do estado. Antônio Maria era um renomado militar que participou da retomada de Corumbá das forças paraguaias, em 1867, durante a Guerra do Paraguai (1864-1870), “...o grande prestigio da classe militar confirmou-se com a própria indicação de Maria Coelho que, contrariamente, se chocava com os interesses de parte considerável do coronelismo regional" (CORRÊA, 2006, p.87).

Contudo, Antônio Maria Coelho ainda não havia superado a sua não indicação para o Senado Imperial pelo Partido Liberal. Em seu lugar fora escolhido Joaquim Murtinho, este desde os fins do Império tentava entrar na política sendo repetidas vezes preterido. Quando acabara de se eleger, é proclamada a República e não pode assumir (FARIA, 1993, p.180-194).

O governador fundou o PNR (Partido Nacional Republicano), composto pelas pessoas que outrora estavam no Partido Conservador. O PNR excluía os antigos liberais e privilegiava os antigos conservadores. Generoso Ponce, chefe do Partido Liberal, 


\section{ELITES POLÍTICAS MATO-GROSSENSES E AS DISPUTAS OLIGÁRQUICAS}

DE 1892, 1899 E 1906

lançou manifesto conclamando a criação do Partido Republicano, para contrapor ao do governador e recebeu apoio de Joaquim Murtinho. Forma-se então dois blocos, de um lado o governador com PNR, e do outro Ponce e os Murtinho, do Partido Republicano.

O ponto da discórdia entre os dois grupos foram as eleições realizadas em janeiro de 1891, vencida pelo PNR. Joaquim Murtinho, que tinha muitos contatos no Rio de Janeiro, conseguiu com Deodoro a demissão do governador Antônio Maria.

Deodoro nomeou para governo estadual Frederico Sólon Sampaio Ribeiro, que anulou as eleições de janeiro. Marcadas novas eleições para maio de 1891, a vitória dessa vez foi do Partido Republicano e o novo presidente Manuel Murtinho. Como bem observado, “...quem controla os cargos ganhava as eleições” (MENEZES, 2007, p.15).

Ainda durante o ano de 1891, Deodoro dissolveu o Congresso e a crise política resultou na sua renúncia. Assumiu Floriano e processou-se nos estados as derrubadas de governadores que apoiaram Deodoro, Manuel Murtinho havia defendido o marechal. De modo que o "adesismo político de Murtinho, portanto, favoreceu o processo conspiratório da oposição, que se concretizou na revolução iniciada na cidade portuária de Corumbá (22.01.1892) e não na capital do estado que era o centro nervoso da política mato-grossense" (CORRÊA, 2006, p.92).

Uniram-se, então, no PNR os militares e os comerciantes de Corumbá, em contraposição ao Partido Republicano, de Generoso Ponce e os Murtinho. De acordo com Corrêa (2006) a participação dos militares foi uma tentativa dos mesmos retornarem ao poder após a chegada da oligarquia dos Murtinho. Houve participação dos comerciantes, sendo muitos deles estrangeiros.

O confronto se deu entre o "Exército Floriano Peixoto", liderado por Ponce, e o "Batalhão Antônio Maria”. Quando Floriano ficou sabendo da situação de Mato Grosso, nomeou o general Ewbank para o governo estadual. Porém, os militares - que controlavam o rio Paraguai 3- entenderam a nomeação como uma afronta a autonomia estadual e não permitiram que o general entrasse no estado. Essa ruptura da hierarquia militar e desobediência ao poder central foi usada pelo Partido Republicano contra seus opositores.

Outro fato que torna o conflito mais atípico dos três e das demais lutas ocorridas no estado durante a República Oligárquica é o caráter separatista. Os revoltosos queriam a separação do país; seria o "Estado Livre do Mato Grosso". O estado queria ajuda financeira da Inglaterra para lutar contra o Brasil por sua Independência. A Inglaterra acreditava que por trás da Independência do Mato Grosso estava a Argentina, pois o Brasil não teria mais motivos para interferir na bacia da Prata

$3 \mathrm{O}$ rio Paraguai era a única forma de entrar em Mato Grosso à época. Do Rio de Janeiro a Cuiabá passava-se por três países: Uruguai, Argentina e Paraguai. 
(MENESES, 2007). Os comerciantes corumbaenses ligavam-se aos interesses argentinos (CORRÊA, 2006, p.99).

Os longínquos contatos da província do Mato Grosso com o resto do país, o tornava mais ligado à Europa, via bacia do Prata (NEVES, 2001, p.76) e aos países platinos, do que ao próprio Brasil. Essa situação só se altera em 1914 com a chegada da Ferrovia Noroeste do Brasil, aumentando o contato com São Paulo (Menezes, 2007, p.11-27). Corumbá por ser uma cidade portuária e de fronteira se identificava mais com os outros países do que com o Brasil.

Visto que as forças de Ponce estavam vencendo, a intendência municipal de Corumbá afirmou não querer se separar do Brasil. Os comerciantes de Corumbá abandonam os militares, pois os negócios estavam sendo prejudicados em decorrência do conflito (CORRÊA, 2006, p.102).

A Disputa Oligárquica de 1892 não passou do enfrentamento entre os partidos Republicano e Nacional pelo comando político estadual. Os partidos eram formados pelas mesmas pessoas que compunham os partidos Liberal e Conservador do Império, que mantiveram as antigas rivalidades. A separação, como se sabe, não foi concluída e a vitória do Partido Republicano sela a aliança oligárquica entre Ponce e Murtinho.

\section{IV-A Disputa Oligárquica de 1899: cisão das oligarquias Ponce e Murtinho}

Depois dos fatos de 1892, Generoso Ponce alcançou grande prestígio no estado. Em 1898 já sondava um nome para as próximas eleições pelo Partido Republicano. Consultou todos seus chefes locais por meio de cartas. Um desses chefes eram os irmãos João e Antônio Paes de Barros. Todos os chefes locais indicaram para a próxima eleição o nome de Generoso Ponce e sinalizam que votariam em quem este ordenasse. Poucos indicam nome, o que foi feito pelo os irmãos Paes de Barros. O escolhido de Ponce foi João Félix Peixoto de Azevedo, indicado de João Paes de Barros.

A maioria não ousou questionar Ponce quanto à adesão da candidatura de João Félix; Totó Paes sim. Pedro Celestino Correa da Costa ameaçou as atividades comerciais de Totó, que respondeu: "é assaz reconhecido pela justiça que faz-me de nunca subordinar minhas opiniões a qualquer classe de interesse, seja ela da ordem que for" (MENEZES, 2007, p.53). Comunicou a Pedro Celestino que não votaria no candidato de Ponce.

Os Murtinho, receosos do grande poder político de Generoso Ponce, romperam com este e apóiam Metello. O Partido Republicano se cindiu, de um lado Ponce e João Félix, de outro Metello, os Murtinho e Totó Paes. Para abarcar a nova configuração foram criados dois partidos: o Partido Republicano Constitucional, de Totó Paes e os Murtinho; e o Partido Republicano Conservador, de Ponce e os Corrêa da Costa. 
Enquanto isso, no governo federal assumiu a presidência Campos Salles em 1898, cujo um de seus principais legados foi a política dos governadores. A política consistia em usufruir dos grandes poderes dos governadores, já que a descentralização outorgava poderes a estes, criando um sistema de reciprocidade e apoio mútuo. Assim, só se elegiam aqueles que apoiavam a política realizada pelo governo federal. Campos Sales pretendia afastar as contendas estaduais, para ocupar a presidência com grandes questões.

Dessa maneira a oposição não alcançava o poder pelas vias eleitorais. Nos estado "fieis" ao presidente da República a oposição só podia esperar por algum desentendimento, pois o presidente ajudava em tudo os seus partidários. Portanto, segundo a lógica inventada pelo próprio Campos Salles, o presidente deveria apoiar quem detinha apoio da maioria no estado, que no caso era representado por Ponce e seus aliados. Menezes (2007, p.53-63) relata que Metello só aceitou concorrer se Ponce não entrasse na disputa, pois seria certa a derrota.

Porém, Joaquim Murtinho era amigo e ministro de Campos Salles e não perdeu a oportunidade de influenciar em seu estado natal através do presidente. Assim, quando as eleições foram realizadas em 01/03/1899, devido à grande influência de Ponce, João Félix venceu.

No dia 10 de abril de 1899 a Assembleia Legislativa deveria referendar as eleições, e Ponce era presidente da casa. As tropas do coronel Totó Paes cercaram a Assembleia, a fim de impedir que fossem diplomados os candidatos eleitos. O governador e Ponce apelaram para todas as instâncias, pedindo que alguma força assegurasse os resultados das eleições, mas foi em vão.

Enquanto entre os dias 09 a 16 de abril Cuiabá foi tomada pelos combates, Totó Paes queria um acordo com Ponce: em troca da anulação das eleições daria garantia de vida a Ponce. Sem apoio do governo federal nem dos militares, através da ajuda de intermediação de Pedro Celestino, Ponce assina um acordo e as eleições foram anuladas.

Realizadas novas eleições, Ponce retirou-se da capital. A partir de então Totó Paes detinha o poder político. Nessa nova cisão ficam de um lado os Paes de Barros e os Murtinho, e de outro os Ponce e os Corrêa da Costa.

\section{V- Disputa Oligárquica de 1906: o assassinato do governador Totó Paes}

Em 1902 foi eleito o presidente Rodrigues Alves e, em 1903, Totó Paes no governo de Mato Grosso. No período em que foi governador, Totó envolveu-se em algumas questões que desagradaram os Murtinho, sendo que estes o colocara no governo do estado. 
A primeira contrariedade que Totó impôs aos Murtinho foi sobre o Tratado de Petrópolis. Em novembro de 1903, o Brasil assinou o Tratado com a Bolívia; no acordo o Brasil incorporaria o Acre e parte de Mato Grosso iria para Bolívia.

No Rio de Janeiro, Joaquim Murtinho, Azeredo, Pinheiro Machado e Rui Barbosa faziam oposição a Rodrigues Alves. Dessa maneira, o grupo queria impedir que fosse aprovada no Congresso a questão.

Joaquim Murtinho pediu para Totó fazer oposição ao acordo, assim como Rodrigues Alves pediu para Totó declarar-se favorável. O governador do Mato Grosso decidiu-se por apoiar o presidente da República.

Outro fato ocorreu quando Rodrigues Alves tentou fazer seu sucessor. Joaquim Murtinho, Rui Barbosa e Pinheiro Machado fizeram a Coligação, movimento queria impedir o presidente de eleger seu sucessor. Totó Paes se põe novamente contra os Murtinho e a favor do presidente, apóia Bernardino de Campos, governador de São Paulo.

Diante da autonomia de Totó, Manuel Murtinho e José Metello viajam ao Mato Grosso em 1906 para criar a Coligação no estado, e deu-se o rompimento com Totó. Generoso Ponce que estava em Corumbá foi visitado por estes; eles unem-se em torno da Coligação e contra o governador.

Além dos antigos inimigos unirem-se contra Totó Paes, havia no estado vários militares de alto escalão. Estavam ali como castigo por se oporem ao governo federal, assim, não foi difícil para Ponce unir toda a oposição para somar forças contra Totó Paes. "Totó Paes foi, portanto, o alvo dos Murtinho, Azeredo, Metello, Ponce e seus aliados e também de parte dos oficiais militares federais” (MENEZES, 2007, p.124).

Totó fizera um arriscado cálculo político, se unira ao presidente, porém desconsiderou toda a conjuntura contrária no estado, sem qualquer sustentação com base local. O clima era de muita tensão entre ambas as partes, pois se para o governo havia o medo de um levante, para a oposição a grande perspectiva de repressão - que já estava ocorrendo contra os oposicionistas.

Generoso Ponce estava apenas aguardando o momento certo para iniciar uma ofensiva contra o governador. Mesmo diante do veto contrário dos senadores, Joaquim Murtinho, Azeredo e Metello, os rebeldes mantêm-se firmes no propósito. Formou-se no norte a Legião Patriótica, comandada por Pedro Celestino, e a Divisão Naval Libertadora liderada por Ponce.

Em 16 de maio de 1906 foi tomada a polícia de Corumbá. Em seguida chegou à cidade o coronel Luís Alves Salgado, novo chefe da força federal. O coronel Salgado só assumiu quatro dias depois, pois estava doente, possibilitando a continuidade da ação. 
Fato significativo para a vitória, foi a perspicácia de Ponce em controlar o avanço da ajuda federal em pelo rio Paraguai. Era época de estiagem e no rio só poderia subir embarcações de pequeno porte. Dessa forma, Ponce tomou o cuidado de retirar de Corumbá todas embarcações de pequeno porte e subiu o rio levando toda lenha para dificultar a ajuda a Totó, sem lenha os barcos não tinham como subir.

A ajuda federal tinha sido acionada pelo presidente Rodrigues Alves, que enviou o general Dantas Barreto a Cuiabá. A viagem era longa feita através da bacia da prata. Dantas Barreto partiu em $1^{\circ}$ de junho 1906, e chegou em Corumbá 25 de junho. Como previsto por Ponce, suas embarcações eram grandes, já que havia navios da marinha e no porto não havia embarcações que o ajudassem a subir o rio.

Enquanto isso, em Cuiabá em 21 de junho de 1906, as forças de Ponce tomaram todas posições estratégicas da cidade. Em 30 de junho Ponce intima Totó a se render. O governador fugiu em 02 de julho, refugiando-se em uma fábrica. No dia o6 foi encontrado e assassinado.

Portanto, de acordo com a lógica pessoalista que regia as relações de poder no período, pode-se apontar como uma das causas da morte de Totó Paes, não o fato dele mandar matar oposicionistas, como no caso do massacre da Bacia do Garcez, pois isso era de uso recorrente, mas sim o fato dele não ter feito aliados, amigos para o apoiarem.

\section{VI- As elites e as "Revoluções"}

A República foi encarada como uma oportunidade para alcançar o poder. Assim, houve rápida adesão. Somado à possibilidade de comando político estadual, os conflitos também tiveram uma vinculação econômica, pois foram meio de vida dos ociosos, e enriqueciam comerciantes e coronéis.

Assim, “... as lutas armadas coronelistas em Mato Grosso adquiriram uma função econômica, na medida em que geravam benefícios e privilégios, tais como remunerações (soldos), indenizações, desapropriações de bens, resgates, etc." (CORRÊA, 2006, p.70)

Segundo Corrêa (2006, p.103) a disputa de 1892 inaugurou a utilização de dinheiro público para custear as lutas coronelísticas, para pagamentos, distribuição de armas para as lutas, que dificilmente retornariam ao poder público. Essa última medida resultou na proliferação de grupos armados que transitavam livremente pela fronteira.

É importante considerar que no Mato Grosso Uno o grupo que controlava os cargos do governo controlava também as eleições. O povo obviamente não tinha espaço para real representação nas urnas, sendo que os analfabetos não votavam e os que votavam estavam sujeitos aos benefícios e malefícios do coronel (QUEIROZ, 1976, p160-162). 
Nas três Disputas Oligárquicas há algumas constantes. Primeiro, a perseguição aos adversários, um fato comum e recorrente (LEAL, 1975, p.39). Segundo, acontecimentos de ordem pessoal refletem na política. Por exemplo, o primeiro governador republicano passou a perseguir as pessoas que não o indicaram para o Senado Imperial. E essa também é uma marca da política brasileira, pois as relações são personalistas (HOLANDA, 2009, p 145-147), da mesma forma as relações que se dão em âmbito familiar são projetadas na esfera política (QUEIROZ, 1976: p163). Somado ao fato de o brasileiro nunca ter tido forte noção de diferenciação entre o público e o privado, consequência da hipertrofia do poder privado (DUARTE, 1997: p17-126), fazendo da política um lugar para resolução de questões privadas e não representação dos interesses públicos (QUEIROZ, 1976:p43).

Outro fato importante nas Disputas Oligárquicas foi o desrespeito aos resultados de eleições. Como as instituições foram transplantadas e não criadas aqui, "o Brasil se constituiu em Nação, econômica, cultural e socialmente, em condições altamente desfavoráveis à difusão das idéias democráticas da vida política” (FERNANDES, 2008, p98). Desfavorável, embora não impossível. Por último, a elite política do antigo Mato Grosso, como a do país inteiro (FAORO, 2008, p300), se sentia realmente dona da política, as verdadeiras pessoas que deveriam ter seus interesses representados, em um mandonismo que vem da Casa-Grande (FREIRE, 1963, p78).

Consequentemente, inseridos nessa construção política, esses atores agiram de acordo com a lógica que conheciam, e não a necessária para implantação da ordem democrática, tais como diferenciação entre as esferas pública e privada, solidariedade que possibilite a abstração de um pensamento na coletividade.

Portanto, a hipótese de que as disputas entre as elites produziram as revoluções se confirma, já que as mesmas agiam de acordo com sua racionalidade, e esta um empecilho para a construção de uma ordem efetivamente democrática, problema já apontado por Holanda (2009, p.141-151).

\section{VII- Conclusão}

Quero ressaltar alguns pontos que entendo como permanência na política atual de fatores que se desenvolveram ou consolidaram durante a República Velha. O primeiro deles também destacado por Leal (1975, p.49): se refere ao papel da oposição na política brasileira. Na República Velha não lutavam para derrotar o governo, mas sim para fazer parte do governo, “...para batem-se para disputar, entre si, o privilégio de apoiar o governo e nele se amparar" (Leal, 1975, p.49). Embora tenha sido um avanço político a melhora na competição democrática, o que não existia na Primeira 
República, ainda persiste o fenômeno da conciliação, de lutar para fazer parte do governo.

Outro fator que atravessa nossa história é o pessoalismo, assim como o mandonismo, que regula as relações. Como já foi afirmado acima o governador Totó Paes sucumbiu diante da sua falta de articulação política, ou seja, quem tem amigos não sucumbe. O que ocorreu com Generoso Ponce em 1899, quando Pedro Celestino negociou sua saída com vida do conflito. Pode-se apontar a queda de figuras públicas devido sua falta de articulação política.

Ainda sob a ótica do pessoalismo, da mesma forma que da falta de uma visão da esfera pública, de sentimento coletivo, pode-se apontar os embates na Câmara Federal sobre a votação do Código Florestal. Os que são favoráveis à anistia dos desmatadores o fazem por vários motivos, seja por serem da bancada ruralista, por estarem com pensamento fixo na disputa da presidência da Câmara, ou por apenas reivindicar (chantagear) mais poder junto ao Executivo Federal. A Câmara tem até uma agenda de retaliação para votações, caso a presidente Dilma não libere os cargos que foram prometidos. O que mostra um individualismo, falta de sentimento coletivo para ponderar as discussões de um modo a encontrar alguma solução viável para se ter um desenvolvimento sustentável.

As perseguições aos adversários apontadas por Leal (1975, p.39) e por Corrêa (2006, p.91-138) continuam ainda frequentes, exemplificadas nos assassinados contínuos que vem acontecendo na Amazônia, dos líderes que se posicionam contra os latifundiários.

São patentes as visíveis mudanças que o amadurecimento democrático trouxe a República brasileira, mas ainda convivemos com resquícios de uma política arcaica. Tendo em vista que o Brasil é uma jovem democracia há uma previsibilidade nessas constatações, que ao serem eliminadas, ou amenizadas, acarretarão melhora na qualidade da Democracia. 


\section{Referência Bibliográfica}

CARONE, Edgar. 1969. A Primeira República (1889-1930). $1^{\circ}$ ed., São Paulo: Difusão Européia do Livro.

CORRÊA, V. B.2006. Coronéis e Bandidos em Mato Grosso (1890-1940). $2^{\circ}$ ed., Campo Grande:Ed. UFMS.

DUARTE, Nestor.1997. A Ordem Privada e a Organização Nacional. $2^{\circ}$ ed., Brasília: Ed.UNB.

FAORO, Raymundo. Os Donos do Poder: Formação do Patronato Político Brasileiro. $4^{\circ}$ ed.,São Paulo: Editora Globo,2008, p.279-349

FARIA, F. A. 1993.Os vícios da República: Negócios e Poder na Passagem do Século $X X . v o l .1$, Rio de Janeiro: Notrya Editora

FERNANDES, F. 2008. Mudanças Sociais no Brasil.4ºd.. São Paulo: Editora Global. FERREIRA, G. N. 2009.Visconde de Uruguai: Teoria e Prática do Estado Brasileiro. In: RUGAI, E.B.BOTELHO,A.(org.)Um Enigma Chamado Brasil: 29 intérpretes e um país. Companhia das Letras: São Paulo.

FREYRE, Gilberto. Características Gerais da Colonização Portuguesa do Brasil: Formação de uma Sociedade Agrária, Escravocrata e Híbrida. In:Casa-Grande \& Senzala.13ํed.,Brasília:Editora Universidade de Brasília,1963, p.3-82.

HOLANDA, S. B. 2009.Raízes do Brasil.26ºed., São Paulo: Companhia das Letras. LEAL, V. N.1975. Coronelismo, Enxada e Voto: o município e o regime representativo no Brasil. ${ }^{\circ}$ ed..São Paulo: Editora Alfa-Omega.

LIMA, N. T. 2009. Euclides da Cunha: O Brasil como Sertão In: RUGAI, E. B. BOTELHO,A. (org.)Um Enigma Chamado Brasil: 29 intérpretes e um país. Companhia das Letras: São Paulo.

MENEZES, A. M. 2007. A Morte de Totó Paes: Política no Interior do Brasil. $1^{0} \mathrm{ed}$., Cuiabá:Carlini\&Caniato Editorial.

NEVES, M. M. R. de N. 2001.Origens Formadoras e Identificadoras: Classes Políticas e Divisionismo. In: Leões e Raposas na Política de Mato Grosso. $1^{\circ} \mathrm{ed} .$, Rio de Janeiro: Mariela Editora.

PONCE,G. Senado Federal, Biografia do Senador. Disponível em:[www]. [17/05/2011] PONCE FILHO, G. 1967.O Menino que Era Eu. $1^{\circ} \mathrm{ed}$., Rio de Janeiro: Livraria Lançadora.

QUEIROZ, M. I. P. 1976.O Mandonismo Local na Vida Política Brasileira e outros ensaios. $1^{\mathrm{o} e d . . S a ̃ o ~ P a u l o: ~ E d i t o r a ~ A l f a-O m e g a . ~}$

2006.O Coronelismo Numa Interpretação Sociológica. In: História Geral da Civilização Brasileira. $8^{\circ}$ ed.,Rio de Janeiro: Bertrand Brasil, p.172-212. 
ELITES POLÍTICAS MATO-GROSSENSES E AS DISPUTAS OLIGÁRQUICAS DE 1892, 1899 E 1906

QUEIROZ, P. R. C. 2010.Joaquim Murtinho, banqueiro: Notas sobre a experiência do Banco Rio e Mato Grosso (1891-1902) Est. Hist., Rio de Janeiro, vol. 23, no 45, p. 125146, janeiro-junho. 